\title{
ENCONTRANDO OLHARES
}

Um dos compromissos assumidos pela Revista Sul-Americana de Filosofia e Educação (RESAFE) é a multiplicação de olhares em torno das reflexões sobre as diversas interfaces entre a filosofia $e$ a educação. Estas interfaces se dão, em função das dinâmicas da própria filosofia e da educação, no encontro com outros campos disciplinares e maneiras de pensar a experiência.

Neste número, encontraremos algumas interfaces, alguns encontros de olhares ou olhares se encontrando nas discussões entre a filosofia e a educação. Literatura, política, educação física, são alguns desses outros olhares. A proposta de diversificar os olhares, a partir de seus encontros é uma aposta na positividade da pluralidade frente ao pensamento $e$ as práticas humanas.

O artigo de Alex Sander da Silva discute, a partir de uma perspectiva dialética, as relações entre prática e teoria pedagógicas no que diz respeito ao ensino de filosofia.

Adentrando o multifacetado campo das relações pedagógicas, o artigo de Cristina Rochetti interroga o sentido destas práticas através do rico referencial do filósofo argentino Arturo Roig, enfatizando o caráter relacional do pedagógico na construção e articulação dos saberes.

O texto de Etinete Nascimento Gonçalves faz uma leitura da maneira como as reflexões acerca da verdade aparecem no pensamento do filósofo Richard Rorty e problematiza suas implicações para o campo educacional.

Em uma confrontação entre a noção de amor ao belo em "O banquete" de Platão e "A morte em Veneza" de Thomas Mann, o artigo de Flávio Rovani de Andrade estabelece uma investigação sobre as relações entre literatura, educação $e$ filosofia.

O artigo de Geraldo Adriano Emery Pereira, partindo da obrigatoriedade da presença da filosofia nos currículos no ensino médio, problematizará o lugar da discussão sobre a identidade da filosofia e do filosofar na tensão entre a tradição e a prática filosófica.

FLOR DO NASCIMENTO, wanderson. Encontrando Olhares. Editorial. Revista SulAmericana de Filosofia e Educação. Número 16: maio-out/2011, p. 1-2. 
Estabelecendo uma interface entre filosofia, sociologia e educação física, o texto de Nildo Viana discute o problema da competição que produz uma sociabilidade e mentalidade competitivas, propondo um repensar teórico e prático da educação física que seja capaz de fomentar uma mudança pedagógica sustentada em uma pedagogia autogestionária.

Partindo do contexto das alternativas às perspectivas antropológicohumanistas do pensamento filosófico que ainda apresenta efeitos nos discursos $e$ práticas educacionais, o artigo de Rodrigo Barbosa Lopes traz algumas reflexões acerca do devir e do acontecimento para pensar a educação, a infância e a subjetivação.

O relato de experiência deste número nos conta sobre o Programa Institucional de Bolsas de Iniciação à Docência na licenciatura em filosofia da Universidade Federal da Bahia, em duas escolas da rede pública de ensino da cidade de Salvador.

Que este número seja apenas mais um convite para que os olhares se multipliquem em encontros e, que se encontrando, se multipliquem os pensares.

wanderson flor do nascimento 